\title{
電子線処理による種子の除菌, 殺菌*
}

\author{
小島 啓 安*1
}

（受理1999年10月 4 日，掲載決定2000年 5 月 6 日）

Disinfection of a Seed by Electron Beam Treatment (e-Dressing)

Hiroyasu KOJIMA*1

(SurfTec TransNational Technical Development Div Fujishiro Bldg, 4-30-4 Shinbashi Minato-ku TOKYO 105-0004, JAPAN)

(Received October 4, Accepted May 6, 2000)

\section{1. はじめに}

地球環境の污染が, 近年大きな社会問題となってい る.

環境污染には, 海洋污染, 大気污染, 土壤污染等に分 けられるが, 中でも農薬による土壤污染は, 食品污染に つながり直接摂取することにより健康に影響するものと して，大きくクローズアップされているものの 1 つであ る. 以前から農薬の大量投与による土㥽污染, 土地の疲 弊が指摘されてきた。

その対策として, 低濃度の農薬あるいは無農薬栽培, 有機肥料等の利用が行われ, 又遺伝子組み換え技術を利 用した病気に強い作物の開発等が行われている. 農薬を 使用するのは, 種子の段階と成育過程とがあると思われ るが，種子の処理方法として新しい方法がドイッのフラ ウンフォーファー研究所の電子プラズマ研究所（以下 FEP と称する）で開発され, 実用段階に達したので紹 介する1).

\section{2. 種子の殺菌の歴史}

穀物の種子は，植物の病気に侵されないようにするた めに, 何百年もの間化学薬品を含む様々な処理が行われ てきた. しかしながら，これらの処理は，環境負荷をか けるものが，少なくない，中でも，植物の栽培段階に防 虫・防菌のために大量に薬品を散布する方式は, 土壌污 染や，穀物污染を引き起こすことになる.

* 平成11年 7 月 23 日 第66回真空協会スパッタリングおよびプラズマプ ロセス技術部会定例会にて講演

*1 サーフテックトランスナショナル(㧣) 技術部

（テ105-0004 東京都港区新橋 4-30-4 藤代ビル 3F
表 1 種子…殺菌のための処理の歴史

\begin{tabular}{|c|c|}
\hline 1660 & $\begin{array}{l}\text { 黒穂病に対して穀物から浸漬処理を行った } \\
(\text { ギリス). }\end{array}$ \\
\hline 1761 & 黒穂病に対して硫酸銅を使用. \\
\hline 1873 & 他の病気に硫酸銅を使用. \\
\hline 1888 & 黒穂病に対して，穀物の熱湯処理を行った。 \\
\hline 1895 & $\begin{array}{l}\text { ホルムアルデヒドを用いて種子の処理を行っ } \\
\text { た. }\end{array}$ \\
\hline 1910 & 炭酸銅を用いて処理. \\
\hline 1912 & 水銀を用いた処理方法の開発. \\
\hline 1960 & 組織的に浸漬方法の開発開始. \\
\hline 1980 & 西ドイッで水銀浸漬が禁止. \\
\hline 1982 & $\mathrm{e}$-処理開発開始. \\
\hline 1995 & $\mathrm{e}$-処理の応用紹介. \\
\hline
\end{tabular}

表 1 は, ヨーロッパに括ける種子の化学的処理の歴史 である．多量の水銀が含有されてしまうような種子の処 理方法は, 問題があり, 現在は禁止されている. 化学産 業の技術は着実に向上してきたが，低コストで大量生産 可能な無公害と言える方法の開発が難しかった．農業と 農業従事者を保護する法律では, なるべく物理的，ある いは生物学的プロセスを利用することを推奖していた が，その方法は現代の生産形態にかなった解決策として は，まだ試行錯誤の段階である.

これに対し，低エネルギーのエレクトロンを使用した 電子線照射（以下 $\mathrm{e}$-処理と称す）は純粋物理学的な過 程であり, 将来性のあるものとされている. このェレク トロンは種子を通過せず，つまり肧芽には全く触れるこ となく, 種子の外皮のみに浸透するので, 新たな種子殺 
電子線照射

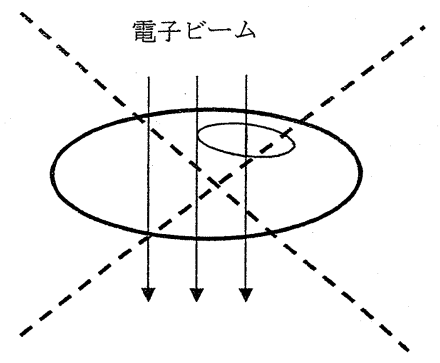

電子ビームは種子を貫通する 胚芽汇破壊される

電子エネルギーは 500kev を超える これは種子には適用できない
電子線処理

(e-dressing)

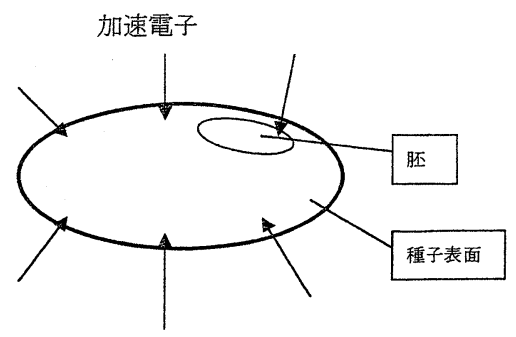

すべての方から電子が種子表面

を処理する。

胚芽には、達しない

電子線エネルギーは、種子の形状 に依存する

図 $1 \mathrm{e}$-照射のモデル

菌法として，非常に有望視されている．この見取り図を 図 1 に示す.

$\mathrm{e}$-処理は，放射線照射とは全く異なるものであり，正 確に測定するならば，低エネルギーのエレクトロンの使 用量は, 種子の外皮厚部分だけ浸透するくらいの, つま り冬小麦の $\mathrm{e}$-処理でいえば，50マイクロメーターくら いの厚みである2)。この場合, 病原菌の中で種子内にす でに侵入しているものについては，除外される.

\section{3. 開 発経過}

シーグフーリード・シラー, シーグフリード・パンッ アー，そしてクラウス・ガーバーは，1980年代に旧アル デンヌ研究所において低エネルギーでのエレクトロンを 使用した種子の処理方法を開発した ${ }^{3,4)}$.

1994年にフラウンホーファーに打いて低エネルギーの エレクトロン処理の仕事を引き継ぎ，スポンサーを募っ て，この将来性のあるテクノロジーのプロジェクトをは じめ，パイロット・プラントである「WESENITZ 1（ヴ ェゼニッツ1)」をへルムドルフに設置することを決定 した.

この「WESENITZ 1」といらプラントは1995年に完 成し，かなりの量の種子を $\mathrm{e}$-処理できる，農業実験用 としては十分な規模のものとなって和り, 生産プラント のコスト試算等が行われた.

このプロジェクトの当初から FEP のドレスデンで働 く物理学者あるいはエンジニア達と現在 “BBA（ドイ ツ連邦農業森林生物研究財団)”の一部である先端植物 防疫研究所の微生物学者である, ウルリッヒ・ブルッ, ケルシュティン・リンドナーもこのプロジェクトに加わ り密接な協力をしている. この桁外れに大規模なフィー ルド・テスト（屋外実験）の多くは，クヴェドリンブル グのライナー・ハインッマン・エンタープライズ社の協
力によるものである.

長い年月をかけて行われてきた調査やテストを経て, ドイツ連邦研究所 BBA は, e一処理を広範囲に普及させ る許可を出した.すでにザクセン州やゼクセン・アンハ ルト州では30以上の団体が， $\mathrm{e}$-処理を利用して拈り，そ して FEPは，その処理過程におけるパラメータが安全 圏内である,といら保証もしている1).

\section{4. e-処理方法}

e一処理方法は図 2 のよう構成により行われている. この装置は「WESENITZ 1」と呼ばれているパイロッ トプラントであり, ドレスデンから南西に $20 \mathrm{~km}$ 下った ところの, FEP のへルムスドルフ農場に置かれている.

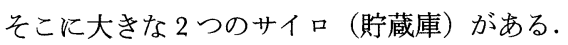

そのひとつには少し傾斜がつけられて拉り，ベルト・ コンベアーによって建物の底辺部方向に25トンの小麦の 種子が流れ込むよらになっている．この種子をこのプラ ントの上部に運びここから下に落下させる．

ヘルムドルフのパイロット・プラントは高さが 3 層に 分かれて扣り，数多くのエア・ロックがある. それは, 大気中から真空約 1 ミリバールにするので約千分の一に も圧力を減少させる必要があるからである. そして，こ のポンピングの過程はかなりのエネルギーが投入される ため，FEPによってェネルギーの特別な供給方法の開 発が行われた. 真空室内に投入された後, 種子は扇形に 広げられて, 滝が流れるよらに「 $\mathrm{e}$ 処理・ゾーン」を通 り抜けて落下していく.

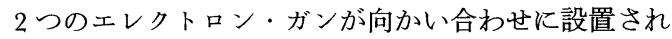
て扣り, エレクトロンは広範囲に散布される。これは, 家庭用の TV ブラウン管から放出される電子線の電圧 26〜 $30 \mathrm{kv}$ と比較しらるくらいの電圧 $60 \mathrm{kv}$ である.

種子は落下している間, あらゆる方向からエレクトロ 


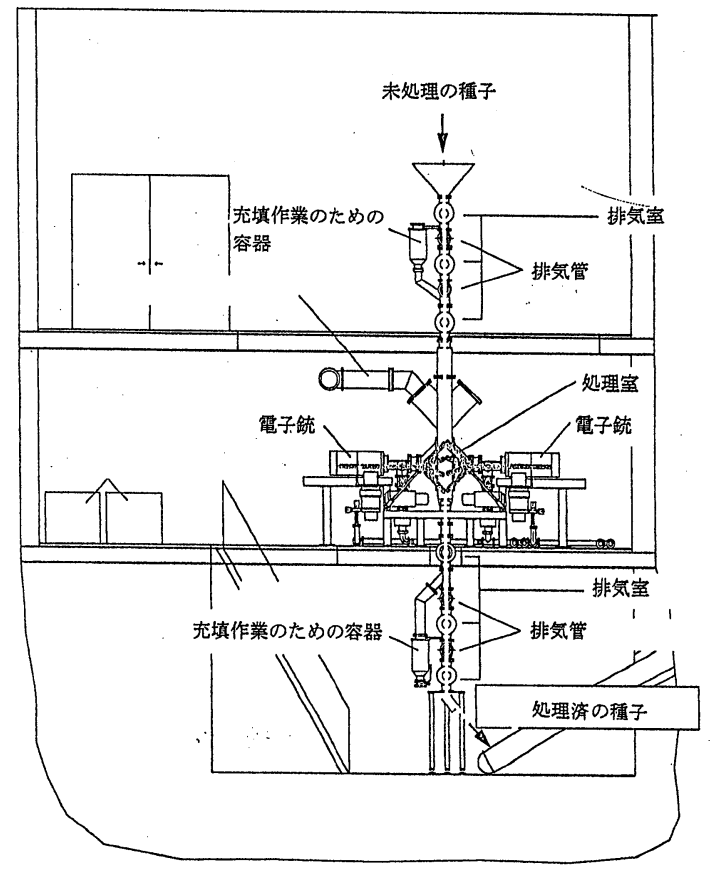

図 2 パイロットプラントWesenitz 1 の構成

ンを受け，照射量・約 $8000 \mathrm{~W} / \mathrm{Kg}$ ，その時の真空度は $130 \mathrm{~Pa}$ であり, 瞬時のらちに表面の全ての処理が終わ る.一例を挙げると，60,000粒のトウモロコシの種子が 毎秒このエレクトロンの霧を通過するため, 数トン/時 間に相当する。

\section{5. パイロットプラント}

WESENITZ 1 は, 種子の処理部を真空にする必要が あり，これは農業で使用するには不便である．そこで真 空でなく大気中でこの電子ビーム処理をする開発を行っ て拈り, 図 3 がその原理図である。この WESENITZ 2 は既に開発を終了し1996年秋に建設を開始した.

ここで使用する電子銃は，FEPでウェットコーティ ング用（主として sol-gel）の瞬時乾燥に用いるために開 発したものを改良したものである。この新しい $\mathrm{e}$-処理 のプロトタイプは, 毎 1 時間 10 トンの $\mathrm{e}$-処理を供給で きる．現在毎 1 時間25トンになるよう努力している.

WESENITZ 2 は, 小麦・ライ麦·大麦の $\mathrm{e}$-処理用に 設計されたものであり, この最初のプラントの引き渡し 及び可動可能の設置時期は，2000年を予定している.

ドイッ連邦局からリリースされるライ麦及び人麦の種 子用の装置は2001年頃になる。この計画とは別泟 FEP は近年, 穀物処理の専門業者であるザクソン州デベリン の “シュミット AG 兄弟商会”と提携を結んだ. この 会社は, e-処理のプラントを製造し，ヨーロッパで販売 する計画を立てている，その最初の試みが，ドレスデン

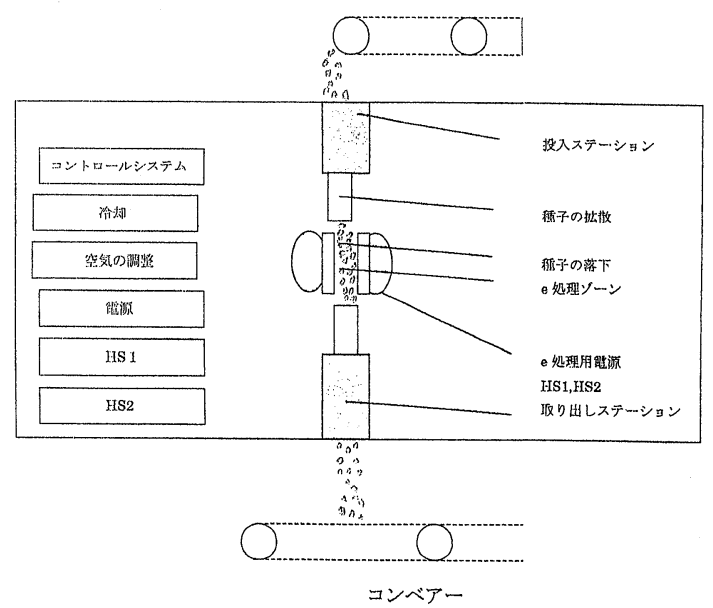

図 3 Wesenitz 2 の原理

の近くのルッペンドルフ農業協同組合に和ける新しい製 造プラント計画で，1998年の収穫時期に稼働する予定で ある。

1997年の收穫時期以は，抒よそ1000トンの冬小麦が e-処理され，「WESENITZ 1」の操業上に関する信頼性 も十分で，この処理方法が期待に添えることを証明し た. 種子業者は, e-処理の効果に大きな期待をして拉り 化学的処理方法に比べより経済的である認識を持ってい る.この $\mathrm{e}$ 処理がぞの程度魅力的な価格になるかが注 目されている.

\section{6. 費用}

実際の農業用の処理装置として考える場合にコストが 重要な点である。この方法では初期投資に大きな資金が 必要であるが，その後のランニングコストは低い，予想 されるぺイバックタイムとその後のコスト比較したのが 図 4 である. 化学的処理方法では初期投資は小さいが, コストは下がらない. パイロットプラント段階での予測 では, 種子の 1 時間当たりの処理量にもよるがプラント の価格は300万〜 400万マルクである. $\mathrm{e}-$ 処理の費用自体 は, 化学処理の費用よりもかなり低価格となっており, 1トン当たり50〜120マルクぐらいである1).

\section{7. まと め}

- $\mathrm{e}$-処理は, 種子に発生する病原菌に対して有効な殺菌 効果を示す.この処理法は, 現代農業の要求に対し満 足のいく結果をもたらしている.

・種子の表面就よび種子の外皮から病原菌が取り除かれ $る^{5-7)}$.

・種子の形態によりェレクトロンのエネルギーを調査す ることにより浸透の厚さを変えられることが可能とな り植物には無害である2). 
ペイバックタイムの間のコスト比較

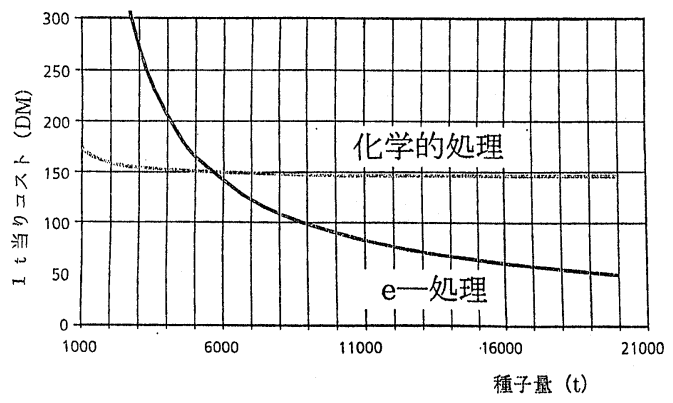

ペイバックタイム後のコスト比較

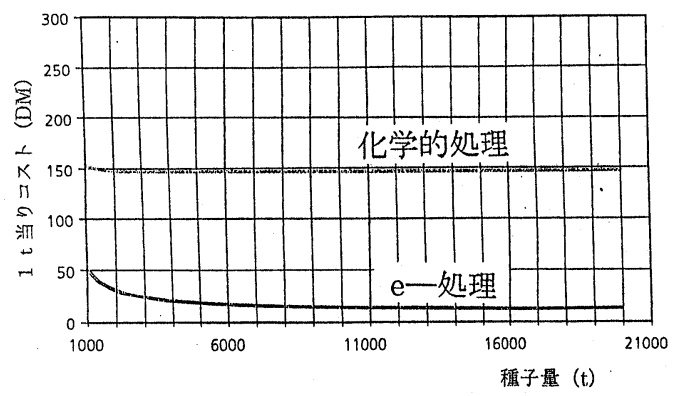

図 4 ペイバック前後のコスト比較

・手で触れたり口に入れて飲反込んでも，人体及び動物 と無害である.

- $\mathrm{e}$-処理の結果は, 作物自体の生育状態をみても穀物の 生産高を見ても, 化学的処理法と比較したとき, 何ら 遜色がな(1).

・化学的な処理方法ではないので, 草木や土壌を污染す る心配がない。

又，この技術に関してブルンスヴィック（ブラウンシ ュヴァイグ/クラインマッハノウ）の BBA による広範 囲な調查と試験の結果, e-処理方法は, この公的機関に 認められ, 推奖された.

FEP は, 種子の $\mathrm{e}$-処理は, 種子の成長一切を損なわ ないことを仕様証明書を発行し保証している11).

\section{8. 終わりに}

はじめに述べたように, 地球環境保護が全ての分野で 非常に重要になってきている．農業分野への取り組みは 影響が直接的であり，大きいため時間がかかることが多 い.

ドイッでは小麦の栽培だけで年間1000トンを超える化 学物資 (農薬) が土壌に混入している.土壌污染は一般 の人が食品を掑取することに寄る健康被害だけでなく， 農業従事者が，化学薬品を取り扱う際に，吸収すること による労衝衛生上の問題も大きい。

このよらな開発は，1 民間企業あるいは 1 研究所では 難しい。ドイッの例で見るように政府関係機関，大学， 農業団体等の緊密な協力が不可欠である. 日本の場合も 国及び自治体の積極的な推進，助成が望まれる

\section{〔文献〕}

1) S. Schiller, O. Röder, FEP annual report 1997, 20

2) Röder, O., Knappe. U (1997): Die Elektronenbehandlung, eine physikalikalische Alternative zur chemischen Beizung von Saatgut. Mitteilung a.d.Biol. Bundesanst. Land-Forstwirtsch. Issue 329: 46-52.

3) Gaber,K., PanzerS., Schiller, S. et al (1983): German patent DD242337Al.

4) Gaber, K., Panzer S., Schiller, S. et al (1990): German patent DD291 704 B5.

5) Lindner, K. (1992): Untersuchungen zur phytosanitären Wirkung einer Behandlung von Winterweizensaatgut mit niederenergerischen Elektrone. PhDthesis, Faculty "Landwirtschaft und Gartenbau", Humboldt University, Berlin

6) Lindner, K., Burth, U., Röder, O. (1996): Einführung der Saatgutbehadlung von WinterWeizen mit niederenergetischen Elektronen in die landwirtschaftliche Praxis. Mitteilungen a.d.Biol. Bundesanst. Issue 321: 50 .

7) Lindner, K., Burth, U., Jahn, M., Müller, P., Scholze, G., Gaber, K. (1990): Die Wirkung der Elktronenbeizung auf ausgewählte samenbürtige Schaderreger und die Getreidepflanze. 6th Internatioal Symposium "Schaderreger des Getreides", Halle/Saale, conference proceeding: 341-342.

8) Schöder, T., Röder, O. and Kerstin Lindner ISTA News Bulletin 118, (1998). 13. 